PUBLIK: Jurnal Manajemen Sumber Daya Manusia, Adminsitrasi dan Pelayanan Publik Sekolah Tinggi Ilmu Administrasi Bina Taruna Gorontalo Volume VII Nomor 22020

\title{
SINERGI KADES, BPD DAN PENGURUS BUMDES DALAM MEWUJUDKAN PENDAPATAN ASLI DESA MELALUI KEGIATAN BUMDES
}

\author{
Shanti Veronica Br. Siahaan'; Benedhikta Kikky Vuspitasari² \\ Institut Shanti Bhuana Bengkayang \\ siahaan.shanti ${ }^{1} @$ shantibhuana.ac.id1; kikky²@shantibhuana.ac.id
}

\begin{abstract}
ABSTRAK
Penelitian ini dilakukan bertujuan untuk mengetahui faktor-faktor apa saja yang menjadi pembentuk sinergi Kepala Desa, BPD dan Pengurus BUMDes dalam upaya mewujudkan pendapatan desa melalui kegiatan BUMDes di Desa Cipta Karya, Kecamatan Sungai Betung, Kabupaten Bengkayang, Kalimantan Barat. BUMDes Panyanggar yang telah berdiri di akhir tahun 2015 mengalami masa kevakuman selama satu periode kepengurusan, namun di periode kepengurusan yang kedua, dalam waktu kurang dari satu tahun telah berhasil menghasilkan pendapatan asli desa. Hal ini tentunya menggembirakan banyak pihak dan membawa semangat baru dalam melihat eksistensi BUMDes yang diharapkan dapat menjadi motor penggerak perekonomian desa serta member inspirasi bagi desa di sekitarnya yang sudah memiliki BUMDes namun kehadirannya masih sebatas nama di atas kertas. Metode penelitian ini menggunakan pendekatan penelitian kualitatif deskriptif dengan nara sumber yang dipilih secara purposeful sampling yaitu Kepala Desa, Penjabat Kepala Desa, Pengurus BUMDes dan Ketua BPD Desa Cipta Karya dimana peneliti menjadi pemeran serta dalam penelitian dengan melakukan pengambilan data dengan cara observasi, wawancara mendalam dengan cara bertemu langsung atau pun melalui media Whatsapp dan telepon seluler serta dokumentasi kegiatan BUMDes. Hasil penelitian ini adalah terjalinnya komunikasi yang baik dalam kerjasama serta kreativitas usaha yang seimbang dengan kepentingan masyarakat telah membentuk sinergi keberlanjutan pembangunan di desa Cipta Karya.
\end{abstract}

\section{Kata Kunci: BUMDes; Komunikasi; Kerjasama, Kreativitas; Sinergi; Desa}

\section{ABSTRACT}

This study was conducted to determine what factors form the synergy of the Village Head, BPD, and BUMDes Management to realize village income through BUMDes activities in Cipta Karya Village, Sungai Betung District, Bengkayang Regency, West Kalimantan. BUMDes Panyanggar, was established at the end of 2015, experienced a vacuum period for one period of management, but in the second period of management, in less than one year it had succeeded in generating the village original income. This certainly makes many parties happy and brings new enthusiasm in seeing the existence of BUMDes which is expected to be a motor to drive the village economy and to inspire surrounding villages that already have BUMDes but their presence is still limited to a name on paper. This research method used a descriptive qualitative research approach with resource persons selected by purposive sampling, namely the Village Head, the Village Head, the BUMDes Management, and the Head of the Cipta Karya Village BPD where the researcher became a participant in the research by taking data by observation, in-depth interviews through meet in person or through WhatsApp and 
PUBLIK: Jurnal Manajemen Sumber Daya Manusia, Adminsitrasi dan Pelayanan Publik Sekolah Tinggi Ilmu Administrasi Bina Taruna Gorontalo Volume VII Nomor 22020

cell phone media and documentation of BUMDes activities. The results of this study are the establishment of good communication in cooperation and business creativity that is balanced with the interests of the community has formed a synergy for sustainable development in Cipta Karya village.

Keywords: Village-Owned Enterprises; Communication; Cooperation; Creativity; Synergy, Village

\section{PENDAHULUAN}

Keelokan wisata bukit Sepancong (Sepadang Hill) di desa Cipta Karya telah memikat banyak wisatawan lokal dari berbagai tempat di Kalimantan Barat untuk datang mengunjungi lokasi ini. Sudah ada ribuan orang telah datang berkunjung menikmati keindahan panorama alam dan berbagai fasilitas swafoto instagenik yang disediakan di lokasi wisata ini. (Dedi, 2020). Selain Sepadang Hill (Bukit Sepancong Spot 2) dan hutan anggreknya, sebagai keberlanjutan pengembangan wisata alam di Desa Cipta Karya telah dibuka lokasi wisata lainnya yang masih dalam masa pembinaan dan masa uji sebelum dibuat Memorandum of Understanding (MOU) atau nota kesepakatan kerjasama antara BUMDes dengan desa yaitu Bukit Pajamet dan Riam Palayo, serta Bukit Salapar dan Batu Bide yang memiliki panorama alam yang tak kalah menariknya dengan Bukit Sepancong. (Kiwi, 2020). Lokasi wisata ini terus mendapat perhatian secara penuh dan ditangani secara professional sebagai hasil kerja keras BUMDes Panyanggar yang didukung oleh pemerintahan desa khususnya KepalaDesa dan juga Badan Permusyawaratan Desa (BPD) Desa Cipta Karya.

Kiprah badan usaha milik desa dalam membangun perekonomian desa di Indonesia dapat dirasakan oleh berbagai desa yang secara serius telah menjalankan program pemerintah ini. Namun tidak semua desa yang telah memiliki BUMDes dapat merasakan kehadiran BUMDes yang mampu menjadi penggerak perekonomian desa karena disebabkan oleh berbagai faktor penghambat yang muncul dalam pelaksanaan kegiatan BUMDes ini. Tantangan yang paling utama adalah peranan Kepala Desa sebagai pengambil keputusan utama dalam setiap program yang dijalankan oleh BUMDes. Kegagalan desa dalam pengelolaan BUMDes dapat terjadi karena ketidaksatuan pemikiran dan tindakan antara Kepala Desa dengan pengelola BUMDes seperti hasil penelitian di Kabupaten Banyumas yang menunjukkan bahwa relasi bisnis yang terjadi belum saling menguntungkan. (Kurniasih\& Wijaya, 2017).

Pemahaman tentang BUMDes secara benar mutlak diperlukan oleh semua elemen terkait dalam pelaksanaan BUMDes di desa. Selain itu, sumber daya manusia yang mumpuni juga diperlukan sebagai pelaksana operasional kegiatan BUMDes ini. Salah satu kriteria yang perlu dimiliki oleh pengurus BUMDes adalah memiliki jiwa kewirausahaan. Dalam diri seseorang yang memiliki jiwa kewirausahaan akan terdapat kemampuan untuk menjalankan usaha secara inovatif, produktif dan pandai dalam mengelola 
resiko. (Sudarko\& Tjitropranoto, 2018). PengurusBUMDes yang memiliki jiwa wirausaha akan mampu melihat peluang potensi dan aset desa yang dapat dikembangkan dengan berinovasi dan memahami pengelolaan risiko yang harus dihadapi dalam iklim perekonomian yang tidak menentu agar dapat terus berjalan menghasilkan pendapatan yang akan digunakan untuk peningkatan kesejahteraan masyarakat.

Salah satu solusi untuk dapat meningkatkan perekonomian suatu masyarakat bahkan suatu negara adalah kegiatan berwirausaha, namun sering kegiatan ini terkendala oleh faktor SDM dan juga faktor modal. (Pio, 2011). Oleh karena itu kehadiran BUMDes dengan pengurus yang berjiwa wirausaha dapat menjadi pendorong bergeraknya perekonomian desa. Tentunya bukanlah hal yang mudah untuk menjadi wirausaha, walaupun semua orang punya bakat berwirausaha namun karakteristik kepribadian yang dimiliki setiap orang akan mempengaruhi keberhasilannya dalam menjalankan rencana usaha tersebut. Menurut Robbins dan Judge (2008), beberapa karakteristik seperti ekstraversi, sifat menyenangkan, sifat mendengarkan kata hati, kemantapan emosional dan keterbukaan terhadap pengalaman menandai kemampuan wirausaha (Pio, 2011).

Kemampuan wirausaha dari pengurus BUMDes juga perlu mendapat dukungan sepenuhnya dari pemerintahan desa khususnya Kepala Desa dan juga Badan Permusyaratan Desa agar dapat terus maju dan berkembang menciptakan lapangan pekerjaan dan memberikan pendapatan asli desa serta turut berperan serta aktif untuk peningkatan kesejahteraan Masyarakat. Hasil penelitian pada Pemerintah Desa Bumiaji menunjukkan bahwa BUMDes telah mampu mencukupi kebutuhan masyarakat karena dukungan dari pemerintah desa Desa Bumiaji yang telah melaksanakan peranan pentingnya dalam upaya pendirian, pengembangan dan peningkatan BUMDes di desa tersebut (Chintary \& Lestari, 2016).

Hubungan kerjasama antara Pemerintah Desa, BPD dan pengurus BUMDes tidaklah semata-mata hanya untuk membangun suatu kebersamaan dalam penggunaan dana desa untuk pelaksanaan kegiatan BUMDes, namun lebih pada upaya untuk membangun interaksi yang dapat memacu daya piker masing-masing anggota kelompoku ntuk membentuk kreativitas secara kolektif yang dapat bermanfaat bagi lahirnya unitunit usaha yang mampu menyerap tenaga kerja dan memberikan pendapatan bagi desa secara berkelanjutan. Hubungan interaktif antaranggota dalam kelompok akan saling memacu daya pikir, yang pada akhirnya akan menghasilkan gagasan baru, yang berjalan melalui suatu proses yang berkesinambungan sehingga terjadi proses pengembangan pengetahuan dan wawasan yang semakin tinggi kualitasnya. Pengembangan pengetahuan dan wawasan sebagai perwujudan dari sinergi. Sinergi merupakan gabungan dari dua pemikiran yaitu pengertian tentang kerjasama dan sikap kreatif sehingga kesuksesan dalam 
bersinergi menjadi suatu kebutuhan bagi organisasi dalam upaya memperoleh keunggulan bersaing. (Sulasmi, 2017).

Kerjasama dan sikap kreatif di Desa Cipta Karya terwujud dalam kegiatan usaha BUMDes untuk mengelola sektor pariwisata, yaitu wisata alam Bukit Sepancong. Wisata alam ini resmi dikelola oleh BUMDes Panyanggar yang merupakan BUMDes di desa Cipta Karya pada akhir tahun 2019 dan beroperasi di bulan Februari 2020 telah berhasil memberikan sumbangan pertama bagi pendapatan asli desa yang dicatat dalam APBDes tahun 2021. Sektor pariwisata merupakan sektor yang potensial untuk dikembangkan sebagai salah satu sumber pendapatan asli daerah (PAD) dan diharapkan dapat memberikan sumbangan bagi pembangunan ekonomi daerah. Namun jika tidak dikelola dengan baik seperti hasil penelitian pada usaha pengembangan objek wisata pemandian air terjun Bondulayang dilakukan oleh Dinas Kebudayaan dan Pariwisata Kabupaten Gorontalo Utara maka dampaknya pada PAD yang belum meningkat. (Alhadar, 2016). Oleh karena itu perlu kerjasama dan dukungan berbagai pihak terkait untuk dapat mengelola aset daerah sehingga memberikan hasil dan manfaat bagi perkembangan perekonomian daerah.

BUMDes Panyanggar baru bisa beraktivitas dalam menjalankan usaha di sektor pariwisata setalah mendapat dana penyertaan modal desa. Usaha yang mulai dibuka pada bulan Februari 2020 ini sempat ditutup sementara selama 4 bulan, dan meskipun baru berjalan efektif sekitar
3 bulan di tahun 2020 ini, namun penghasilan yang diperoleh telah cukup bagus, apalagi di bulan Agustus, penghasilan bruto BUMDes telah mencapai hampir 40 juta rupiah. Penghasilan ini berasal dari para pengunjung yang datang dan membayar biaya registrasi sebesar sepuluh ribu rupiah per orang dan wisatawan yang membawa sepeda motor akan dikenai biaya parkir roda dua per harinya sebesar sepuluh ribu rupiah. Melihat begitu besarnya animo masyarakat untuk datang dan menikmati keindahan lokasi wisata ini, tentunya menggembirakan bagi semua pihak yang terlibat di dalam BUMDes dan semakin member motivasi untuk berkarya lebih baik lagi. Keberhasilan BUMDes yang baru berjalan beberapa bulan ini tentunya tidak lepas dari sinergi pengurus BUMDes, Kepala Desa dan BPD. Oleh karena itu, maka perlu dilakukan penelitian untuk mengetahui lebih jelas dan mengungkap faktor-faktor yang masih tersembunyi yang membentuk sinergi Kepala Desa, BPD dan pengurus BUMDes dalam mewujudkan pendapatan asli desa Cipta Karya melalui pelaksanaan kegiatan usaha BUMDes.

\section{PERMASALAHAN}

Adapun rumusan masalah dari penelitian ini adalah faktor-faktor apa saja yang membentuk sinergi kerjasama antara pengurus BUMDes Panyanggar, Kepala Desa dan BPD dalam mewujudkan pelaksanaan program BUMDes di desa Cipta Karya, Kecamatan Sungai Betung, 
Kabupaten Bengkayang, Kalimantan Barat.

\section{Tujuan Penelitian}

Tujuan dari penelitian ini adalah untuk mengetahui faktor-faktor apa saja yang membentuk sinergi kerjasama antara pengurus BUMDes Panyanggar, Kepala Desa dan BPD dalam mewujudkan pelaksanaan program BUMDes di desa Cipta Karya, Kecamatan Sungai Betung, Kabupaten Bengkayang, Kalimantan Barat.

\section{Fokus Penelitian}

Penelitian ini difokuskan pada:

\section{Kerjasama}

Kerjasama yang dimaksud adalah relasi hubungan dan perwujudan kerjasama antara Kepala Desa, BPD dan Pengurus BUMDes dalam perencanaan kegiatan, pelaksanaan dan pengawasan kegiatan unit usaha yang dijalankan oleh BUMDes Panyanggar.

\section{Sikap Kreatif}

Sikap kreatif yang dimaksud adalah hubungan interaktif yang melahirkan ideide baru dalam mengembangkan unit-unit usaha BUMDes di Desa Cipta Karya, Kecamatan Sungai Betung, Kabupaten Bengkayang, Kalimantan Barat.

\section{METODE PENELITIAN}

Penelitian ini menggunakan metode penelitian deskriptif kualitatif, dimana metode ini digunakan untuk menganalisis aktivitas dan fenomena sosial yang terjadi pada saat penelitian dilakukan. Penelitian ini dilakukan pada BUMDes Panyanggar di Desa Cipta Karya, Kecamatan Sungai Betung, Kabupaten Bengkayang, Kalimantan Barat yang berhasil menjalankan unit usaha lokasi wisata di tahun 2020 dan telah memberikan pendapatan asli desa di tahun 2020. Adapun tahapan penelitian ini adalah sebagai berikut: (1) Diskusi awal dengan Kepala Desa dan pengurus BUMDes, (2) Studi Literatur dengan melakukan proses kajian terdahulu dan penelitian-penelitian BUMDes yang relevan, (3) Pengumpulan data penelitian melalui kegiatan yang dilaksanakan dengan cara wawancara mendalam secara langsung atau pun lewat whatsapp video call, percakapan di whatsapp dan telepon seluler terhadap narasumber yang dipilih secara purposeful sampling. Yaitu Kepala Desa, Penjabat Kepala Desa, Ketua BPD dan pengurus BUMDes Panyanggar, Observasi langsung serta mengumpulkan informasi dokumentasi terkait kegiatan BUMDes yang sudah ada seperti Perdes tentang pengangkatan pengurus BUMDes, AD/ART BUMDes dan informasi tentang BUMDes dari berbagai media massa, (4) Analisis data dengan tahapan analisis data yang digunakan menurut Matthew B. Miles dan A. Michael Huberman (Miles et al., 2014), yaitu reduksi data dari transkrip hasil wawancara, penyajian data, simpulan atau verifikasi, sedangkan teknik pemeriksaan keabsahan data dalam penelitian ini menggunakan teknik triangulasi, kemudian (5) Rekomendasi dan Kesimpulan. 


\section{HASIL PENELITIAN DAN PEMBAHASAN}

Desa Cipta Karya telah memiliki BUMDes bernama BUMDes Panyanggar yang berdiri pada akhir tahun 2015 dengan Perdes No. 3 Tahun 2015. Masa jabatan kepengurusan BUMDes di Desa Cipta Karya ini adalah selama empat tahun, dan telah terjadi dua kali pergantian pengurus dengan Direktur BUMDes yang terpilih dari hasil musyawarah desa tetap sama. Periode pertama kepengurusan BUMDes belum ada unit usaha yang dijalankan disebabkan karena baik Kepala Desa maupun pengurus BUMDes belum memahami tentang pentingnya BUMDes dan apa peranan BUMDes di desa, namun setelah Direktur BUMDes mengikuti beberapa kali pelatihan yang diberikan oleh PemDes di Bengkayang, pemahaman tentang BUMDes menjadi lebih baik. Hanya saja, karena kurangnya komunikasi dengan Kepala Desa dan juga perbedaan ide unit bisnis yang ingin dijalankan oleh Kepala Desa dengan pengurus BUMDes sehingga proposal usaha yang diajukan tidak diterima oleh Kepala Desa.

Pada periode kedua kepengurusan BUMDes terjadi pula pergantian Kepala Desa dan BPD, momen ini menjadi suatu tonggak baru dalam pelaksanaan kegiatan BUMDes sehingga BUMDes Panyanggar saat ini telah dapat berjalan berkat adanya sinergi Kepala Desa, BPD dan pengurus BUMDes sehingga mampu memberikan pendapatan asli desa di tahun pertama unit usaha pertama BUMDes berjalan. Berikut adalah faktor-faktor yang membentuk sinergi kerjasama antara pengurus BUMDes, Kepala Desa dan Badan Permusyawaratan Desa.

\section{Kerjasama}

Wujud jalinan kerjasama Kepala Desa yang dilantik tahun 2020, BPD dengan kepengurusan yang baru dan pengurus BUMDes tampak dalam jalinan komunikasi yang baik. Kerjasama ini sudah diawali melalui proses keikutsertaan Kepala Desa yang saat itu belum resmi dilantik untuk ikut ambil bagian dalam perencanaan unit usaha BUMDes yang mendapatkan dana penyertaan modal desa yang bersumber dari sisa anggaran desa yang tidak digunakan sampai akhir tahun 2019.

Adapun keputusan untuk menggunakan sisa anggaran tersebut berawal dari PJ Kades Cipta Karya yang dilantik tanggal 19 Desember 2019 diundang rapat oleh BPD pada tanggal 20 Desember 2019 malam untuk membicarakan sisa anggaran desa yang belum terserap. Setelah mendengar keterangan dari BPD, Sekretaris Desa, Bendahara Desa dan pengurus BUMDes, bahwa di atas $80 \%$ kegiatan unit usaha BUMDes telah siap berjalan hanya belum ada modal, dan belum mendapatkan suntikan dana dari desa. Selain itu, PJ Kades yang merupakan salah satu warga desa Cipta Karya juga telah mengetahui bahwa ada kegiatan pencinta alam, warga setempat di desa tersebut yang sering mengeksplorasi keindahan alam desa dan pernah juga terlibat dalam kegiatan mendaki bukit Sepancong bersama anakanak Pramuka serta menyadari bahwa aset desa tersebut dapat dikelola dan 
member pemasukan bagi desa, sehingga PJ Kades dapat memahami dengan baik usulan dari BUMDes Panyanggar tentang rencana mengelola aset tersebut.

Anggota pengurus BUMDes juga merupakan penggiat pencinta alam dan sudah mempersiapkan proposal pendirian unit usaha BUMDes. Di akhir tahun 2019, anggaran desa sangat memungkinkan karena dari pos-pos yang dianggarkan ada dana desa yang tidak terserap, dan jika masih ada dana berlebih yang tidak lagi dapat dimasukkan dalam SILPA karena adanya aturan batas maksimum, maka kelebihan dana desa tersebut akan dikembalikan ke pemerintahan pusat. Di sisi lain, desa telah memiliki BUMDes yang belum mendapat anggaran dana desa, oleh karena itu dari pihak desa yaitu BPD, Sekretaris desa, Bendahara desa berembuk dan mengusulkan kepada PJ Kades untuk memberikan dana tersebut bagi kegiatan usaha BUMDes.

PJ Kades sendiri melihat BUMDes dapat membawa pendapatan bagi perkembangan desa karena selama ini pembangunan di desa Cipta Karya lebih pada pembangunan berbagai fasilitas desa yang berfungsi untuk digunakan seperti jalan tani, dan lainnya yang jika rusak, tidak ada anggaran biaya untuk memperbaikinya jika tidak ada pendapatan dari desa itu sendiri. Selain itu, adanya program kucuran dana langsung dari pemerintahan pusat untuk desa belum tentu akan terus ada, dan jika suatu saat anggaran desa tersebut dihentikan, desa akan mengalami kesulitan untuk membangun dan memelihara semua fasilitas yang sudah ada jika tidak ada modal sendiri dari desa atau pendapatan asli desa. Pertimbangan lain adalah kesenangan masyarakat untuk berwisata alam, menikmati udara segar dan keindahan alam, seperti Riam Budi, wisata air terjun yang sudah berpuluh tahun lamanya ada, dan telah dikunjungi banyak wisatawan namun karena tidak adanya pengelolaan maka keberadaan objek wisata tersebut belum memberikan manfaat perkembangan perekonomian bagi warga sekitar. Dengan berbagai pertimbangan dan peninjauan langsung ke lapangan, maka PJ Kades bersama tim sebelas memutuskan untuk mengucurkan anggaran yang tidak terserap atau dana dadakan tersebut sebagai dana penyertaan modal bagi BUMDes.

PJ Kades juga melibatkan Kades terpilih yang meskipun belum dilantik untuk ikut serta dalam rapat-rapat penting di desa untuk rancangan tahun 2020 termasuk saat kegiatan peninjauan lahan Bukit Sepancong yang diusulkan untuk dibeli oleh BUMDes. Kades terpilih juga mendukung rencana kegiatan BUMDes tersebut. Di lain pihak, saat Kepala Desa baru terpilih, para pengurus BUMDes juga langsung berkomunikasi, menjelaskan apa yang dapat dikembangkan dan bertukar pikiran untuk dapat menjalankan potensi usaha yang sudah ada dan berjalan namun belum dikelola dengan baik, dan belum ada kepengurusan resmi pengelola. Oleh karena itu, proposal pengajuan dana untuk pengelolaan usaha wisata ini disambut baik oleh Kepala Desa. 
Transfer dilakukan pada tanggal 23 Desember 2019, namun tanggal 24 Desember 2019 BUMDes masih bisa menarik dana untuk pembelian lahan bukit Sepancong. Pengurus BUMDes sudah lama berkomunikasi dengan pemilik lahan bukit Sepancong, sehingga tidak memerlukan waktu lama untuk bernegosiasi menentukan harga beli lahan. Dengan harga yang wajar maka terjadilah transaksi pembelian lahan tersebu tmenjadi aset desa. Adapun transfer dana ke rekening BUMDes tersebut dilakukan setelah BUMDes melengkapi dua belas persyaratan yang harus dipenuhi sebelumnya, yaitu permohonan pencairan, fakta integritas, surat pernyataan tanggung jawab penggunaan penguatan modal usaha BUMDes oleh pelaksana operasional, naskah perjanjian penggunaan penguatan modal usaha BUMDes dari Pemerintahan Desa kepada BUMDes, Perdes pembentukan BUMDes, Perdes penyertaan modal yang disetujui oleh BPD, AD/ART BUMDes, SK kepengurusan, proposal kegiatan / usulan usaha BUMDes dan rancangan usulan biaya (RAB), berita acara penyaluran penyertaan modal BUMDes, fotokopi NPWP dan rekening BUMDes, dan fotokopi ktp ketua BUMDes.

Dana yang diberikan kepada BUMDes ini kemudian dimanfaatkan untuk menjalankan pengelolaan usaha wisata bukit Sepancong. Dana tersebut juga digunakan untuk pembelian lahan yang sebagian besar dimiliki oleh desa tetangga agar mempermudah mencapai akses lokasi wisata dan juga dengan pertimbangan jika hal ini tidak dilakukan maka perlu melakukan MOU pembagian hasil usaha dengan para pemilik tanah. Oleh karena itu dengan persetujuan Kepala Desa yang baru terpilih, dengan pembayaran harga tanah yang wajar, inisiatif untuk membeli tanah sebagai asset desa dan pengelolaannya diserahkan kepada BUMDes dilakukan. Adanya tekad dan kenekatan bersama antara Kepala Desa dan pengurus BUMDes untuk mengambil keputusan pembelian tanah ini karena adanya kerjasama yang dilandasi oleh kepercayaan bersama bahwa bisnis bisa berjalan.

Kepala Desa sudah memahami pentingnya BUMDes bagi desa dan memiliki kepercayaan bahwa BUMDes mampu menggerakkan perekonomian desa. Dukungan Kepala Desa ini merupakan hal yang penting dalam menentukan perkembangan BUMDes. Dukungan Kepala Desa terhadap kegiatan BUMDes dirasakan dengan sikap dan tindakan Kepala Desa yang selalu mau bekerjasama dengan cara aktif berkomunikasi dengan para pengurus BUMDes, kemudian dari komunikasi yang lancer itu maka lahirlah kesamaan pendapat tentang bagaimana menggerakkan perekonomian desa, serta upaya mau mendukung setiap rencana kegiatan BUMDes dan diwujudkan dalam mengganggarkan rencana kegiatan tersebut dalam rencana kegiatan pembangunan desa.

Kepala Desa juga berkonsultasi dengan BPD tentang rencana kegiatan BUMDes, dan BPD telah memiliki pemahaman tentang perlunya kegiatan 
BUMDes untuk dapat menghasilkan pendapatan desa. Keberanian untuk mempertanggungjawabkan penggunaan dana desa dan pemikiran yang sama antara Kepala Desa untuk mau maju bersama mendukung BUMDes menjadi hal yang penting. BPD menyadari bahwa karena tidak adanya dana dari pusat untuk biaya pemeliharaan, desa harus memiliki penghasilan sendiri untuk membiayai pemeliharaan berbagai fasilitas pembangunan yang telah diberikan pemerintah pusat seperti perbaikan jalan yang rusak dan lainnya. BUMDes merupakan kegiatan pemberdayaan masyarakat yang juga menciptakan lapangan kerja sekaligus dapat menjadi sumber pendanaan bagi desa. Salah satu indicator dari berdayanya suatu Desa adalah kemampuan Desa untuk menggali sumber-sumber pendapatan Desa sehingga Desa mampu membiayai kegiatan-kegiatannya tanpa harus memungut iuran dari masyarakat maupun meminta bantuan dari pemerintah seperti Desa Jalancagak, Kecamatan Jalancagak, Kabupaten Subang Provinsi Jawa Barat yang telah memiliki berbagai sumber pendapatan desa. (Saputra, 2017).

Bentuk lain dari perwujudan kerjasama yang baik antara pengurus BUMDes dan Kepala Desa adalah adanya rapat koordinasi secara teratur, diskusi, dilibatkannya BUMDes dalam kegiatan desa, diikutsertakannya BUMDes dalam kegiatan penyusunan rencana kegiatan pembangunan desa (RKPDes). Kepala Desa yang berjiwa muda, terbuka, dan mau menerima ide orang lain mampu memberikan semangat baru dalam melahirkan berbagai gagasan untuk diwujudkan dalam kegiatan pembangunan desa.

Hasil temuan tentang pentingnya membangun kerjasama dan keberlanjutan pembangunan menggunakan dana desa dengan cara melakukan komunikasi terbuka sejalan dengan hasil penelitian tentang penyimpangan yang terjadi dalam pengelolaan dana desa tahun anggaran 2015 dan 2016 di Kabupaten Lombok Timur akibat dari pengelolaan dana desa yang tidak berbasis pada tindakan komunikatif. Organisasi perlu memiliki kerjasama yang dijalankan dengan tindakan komunikatif yang bertujuan untuk menciptakan momen tanpa syarat, dengan klaim validitas yang dapat dikritik, yang menyatu dengan syaratsyarat terbentuknya konsensus, dan bukan hanya berdasar pada keputusan pihak yang dianggap tinggi kelas sosialnya. (Maruhun\& Thatok Asmony, 2019). Oleh karena itu kerjasama yang baik dengan komunikasi yang terjalin baik dapat mendukung sinergi aparatur pemerintahan desa dengan pengurus BUMDes dalam upaya perwujudan cita-cita bersama memajukan desa.

Kepala Desa melihat semangat dan antusias dari para pengurus BUMDes untuk mengembangkan desa sehingga terbentuk jalinan kepercayaan untuk kelanjutan kerjasama. Terobosan yang dibuat pengurus BUMDes membantu pelaksanaan kerja di lapangan, pengkajian permasalahan dan membaca potensi menurut Kepala Desa sangat bagus. Selain itu, pengurus BUMDes juga mampu menjalin komunikasi yang baik 
dan bekerjasama dengan berbagai pihak terkait, seperti dinas pariwisata, pemerintahan desa, hukum, UMKM dan lainnya. Hal ini sangat diperlukan karena BUMDes akan bergerak di segala bidang. Direktur, sekretaris dan bendahara BUMDes bergaul juga dikenal dengan keluwesannya bergaul dan banyak mendapat informasi dari luar.

Kerjasama tim yang solid dan dukungan masyarakat untuk membantu kegiatan promosi di Facebook ataupun Instagram, dan Youtube, juga respon masyarakat yang luar biasa menambah semangat dalam menjalankan misi bersama. Selain itu keterlibatan pengurus BUMDes dalam berbagai jaringan seperti di komunitas pencinta alam Kalbar dan Gempi, Generasi Pesona Indonesia juga sangat membantu dalam promosi lokasi wisata yang saat ini masih ditargetkan untuk masyarakat menengah ke bawah agar masyarakat dapat juga menikmati keindahan alam dengan fasilitas yang terawatt dengan harga terjangkau.

\section{SikapKreatif}

Pada periode pertama kepengurusan BUMDes, saat itu desa juga membuat beberapa kegiatan pelatihan untuk mendukung peningkatan pemberdayaan masyarakat desa, di antaranya yaitu pelatihan ternak kambing, ternak bebek, dan ternak ikan Koi, berdasarkan potensi sumber daya yang ada di desa Cipta Karya. Setelah diadakan kegiatan pelatihan, kemudian ada anggaran dari desa untuk belanja modal mendukung pelatihan tersebut untuk pembelian kambing, ikan Koi dan bebek. Kelanjutan usaha ini kemudian dijalankan oleh
BUMDes namun pengelolaannya kurang memberikan hasil yang memuaskan sehingga keberlanjutan usaha ini tida kterlalu mendapatkan perhatian lebih walaupun masih dapat berjalan bahkan ada yang sudah mati yaitu usaha ternak bebek karena bebek-bebek yang dipelihara satu per satu mati meskipun telah dirawat. Walaupun belum ada usaha resmi yang berjalan, pengurus BUMDes tidak berputus asa dan terus melakukan upaya untuk mencari upaya menjalankan BUMDes di desa mereka.

Dari rapat BUMDes yang dilakukan oleh para pengurus dan anggota didapatkan adanya peluang potensi pariwisata daerah di desa Cipta Karya yang dapat dikelola. Pengurus BUMDes belajar dari daerah Jawa, dan khususnya daerah Bali, sektor pariwisata mampu menggerakkan semua sektor perekonomian lainnya. BUMDes yang diharapkan dapat meningkatkan pendapatan asli desa, harus memiliki usaha yang mampu memberikan keuntungan lebih dan menurut para pengurus BUMDes, desa yang maju dan mampu memberikan pendapatan asli desa yang besar berasal dari sektor usaha pariwisata. Pencarian lokasi wisata yang ingin dikelola kemudian dilakukan oleh pengurus BUMDes, mulai dari usaha untuk bekerjasama dengan kelompok sadar wisata namun saat itu tidak berlanjut pada kesepakatan kerjasama sampai pada pemikiran pencarian lokasi yang sama seperti yang sedang ramai dibicarakan saat itu di media sosial, yaitu wisata Bukit Jamur. 
Desa Cipta Karya sudah memiliki satu tujuan wisata sejenis wisata Bukit Jamur, yaitu Bukit Sepancong yang juga telah sering didatangi oleh para pengunjung. Keindahan bukit ini awalnya diperkenalkan oleh para pencinta alam yang kemudian hari juga ada yang menjadi pengurus BUMDes Panyanggar, lewat postingan yang dilakukan di berbagai media sosial. Lokasi ini juga sudah dikelola oleh RT setempat atas saran beliau dan kemudian hari menjadi unit usaha pertama BUMDes Desa Cipta Karya. Saat menjabat, PJ Kades juga telah mengetahui semangat juang pengurus BUMDes yang walaupun belum ada kucuran dana dari desa namun telah bergerak bersama kelompok pencinta alam untuk memperkenalkan kawasan wisata tersebut melalui berbagai media sosial sehingga sudah banyak wisatawan yang datang berkunjung ketempat tersebut. Bukit yang dulunya setiap musim panas menjadi langganan kebakaran hutan, namun setelah sering dikunjungi oleh pencinta alam menjadi lumayan aman dari kebakaran hutan dan setelah dikelola oleh BUMDes semakin berkembang dan bahkan memberikan pemasukan bagi pendapatan asli desa.

Sejalan dengan visi dan misi yang diusung oleh Kepala Desa yang dilantik tanggal 19 Februari 2020 (Andreas, 2020) adalah berinovasi, mau mengubah apa saja dan mengembangkan apa saja yang sudah ada di Cipta Karya mengingat potensi yang dimiliki cukup banyak untuk kemajuan kesejahteraan masyarakat. Dalam periode 5 tahun kepemimpinan Kepala Desa yang baru dilantik ini targetnya adalah unit usaha di desa Cipta Karya dapat memberikan penghasilan 5-6 juta rupiah perbulan. Jika dalam satu tahun desa dapat memperoleh pendapatan asli desa sekitar 50-60 juta, ada keinginan dari Kepala Desa untuk member subsidi biaya kuliah bagi masyarakat yang tidak mampu. Oleh karena itu, kemudahan perizinan usaha melalui kegiatan BUMDes juga menjadi salah satu dasar keputusan Kepala Desa untuk terbuka terhadap kehadiran BUMDes sebagai penggerak perekonomian desa. Jika pendapatan asli desa dapat diperoleh dari BUMDes, maka kondisi itu akan mendorong setiap Pemerintah Desa memberikan "goodwill" dalam merespon pendirian BUMDes mampu memberikan kontribusi yang signifikan terhadap peningkatan kesejahteraan warga desa. Di samping itu, supaya tidak berkembang sistem usaha kapitalistis di pedesaan yang dapat mengakibatkan terganggunya nilainilai kehidupan bermasyarakat. (Fifianti et al., 2018).

Segala macam jenis usaha akan dapat berada di bawah paying BUMDes. Kehadiran BUMDes dapat mempermudah masyarakat membuka lahan usaha, masyarakat yang punya usaha pribadi atau usaha rumahan dengan modal terbatas namun penjualannya cukup banyak dapat bergabung menjadi unit usaha BUMDes dengan terlebih dahulu dikaji oleh BUMDes, jika telah disetujui maka unit usaha baru tersebut dapat mengajukan permintaan dana penyertaan modal usaha dan membuat MOU perjanjian pembagian hasil usaha dengan BUMDes dan Desa. BUMDes dapat 
mengajukan proposal ke desa, dan bagi desa, pertanggungjawaban untuk menggunakan anggaran akan mudah karena sudah jelas penggunaannya untuk unit usaha BUMDes yang sudah disetujui.

Di akhir tahun 2020, BUMDes Panyanggar juga sudah mulai membina dua kawasan lokasi wisata baru yaitu Bukit Salapar dan kelompok Riam Palayo yang termasuk lokasi Bukit Pajamet. Kedua kawasan ini sudah dibantu untuk dibuatkan lokasi-lokasi foto dan penataan area wisata. Rencana ke depan, di bulan Januari 2021 akan dilakukan MOU sehingga kedua lokasi wisata ini akan menjadi Divisi-2 dan Divisi-3 BUMDes Desa Cipta Karya.

Dalam menanggapi kreativitas dari pengurus BUMDes jika BUMDes merencan akan sesuatu misalnya membuat lokasi spot foto ataupun pembangunan lokasi wisata, BUMDes akan memberikan gambaran ataupun tata letak spot foto yang diusulkan maka Desa yang akan membangunnya dengan bantuan konsultan, setelah bangunan jadi kemudian diserahkan kepada BUMDes untuk dikelola bersama pengelola unit usaha. Penyerahan aset ini disertai dengan berita acara dan MOU antara Desa dan BUMDes, dimana BUMDes menerima hak pengelolaan aset dan ada kewajiban bagi hasil bersih usaha. Selain itu, jika BUMDes akan menambah unit usaha baru, BUMDes akan berdiskusi terlebih dahulu dengan Kepala Desa dan BPD untuk mendapat pertimbangan untuk melihat bersama potensi dan peluang perkembangan unit usaha yang diusulkan di masa mendatang dan persetujuan pemberian dana penyertaan modal desa.

Kepala Desa juga menyadari bahwa kunci keberhasilan desa adalah terletak pada keberhasilan pencapaian visi dan misi Kepala Desa yaitu untuk berinovasi melalui kegiatan yang memerlukan kreativitas sehingga perlu ada kesatuan dari semua pihak yang terkait dalam penyelenggaraan pemerintahan desa. Kepala Desa juga terbuka untuk menerima masukan jika dalam pelaksanaan kegiatan ada yang tidak sesuai, karena menyadari sebagai manusia tentu ada kesalahan yang dapat dilakukannya sehingga perlu ada yang memberitau.

Kepala Desa yang memiliki target untuk penyediaan lapangan pekerjaan agar dapat menambah penghasilan penduduk dan dapat mengurangi pengangguran dengan cara membuka usaha di berbagai bidang. Selain bidang usaha pariwisata, Kepala Desa juga ingin bergerak di bidang usaha air bersih, karena Desa Cipta Karya dulunya dikenal sebagai Desa Sungai Raya, namun desa yang memiliki banyak sungai dengan sumber air yang banyak ini tidak menikmati air bersih. Masyarakat harus membeli air minum gallon dari luar desa. Oleh karena itu, desa merencanakan untuk memiliki unit usaha baru lainnya yang akan dikelola BUMDes yang bergerak dalam bidang penyediaan air bersih.

Untuk itu, Desa dan BUMDes sudah mulai mempersiapkan proses dan berita acara perjanjian dengan masyarakat seperti perjanjian tidak menuntut lahan 
yang akan dibangun dan dilewati pipa air, tidak melubangi pipa air sendiri, mengikuti aturan desa, akan dipasang meteran kubik serta akan ditarik iuran, selanjutnya akan dibuat badan pengelola sumber air minum. Hal ini perlu dilakukanberdasarkan pengalaman sebelumnya dimana tiga unit intake air bersih yang telah dibangun oleh desa telah rusak dan tidak ada pihak yang bertanggung jawab terhadap pemeliharaan tersebut. Jika satu unit usaha intake air bersih ini berhasil dijalankan di tahun 2021, maka fokus usaha di tahun 2022 direncanakan untuk membangun unit intake air bersih yang selanjutnya.

Air merupakan kebutuhan pokok masyarakat, dan BUMDes tidak ingin membebankan masyarakat dengan mengambil keuntungan dari kebutuhan masyarakat ini namun lebih pada biaya operasional dan perawatan peralatan agar lebih terorganisir dengan baik. Oleh karena itu BUMDes akan mengkaji lebih dalam produk kemasan air yang dapat dihasilkan dari usaha air bersih untuk mendapatkan keuntungan dari unit usaha air bersih ini, seperti pembuatan air minum dalam kemasanatau air gallon dan lainnya.

Rencana usaha selanjutnya, desa juga akan bergerak di bidang usaha bank sampah karena sudah ada usaha dari luar desa yang masuk ke desa menawarkan pembelian barang bekas, sehingga perlu juga dibuat suatu unit usaha yang dapat menampung barang bekas yang memiliki nilai ekonomis dan sampah tidak lagi dibuang ke sungai tapi masih bisa ditukarkan dengan rupiah di bank sampah yang akan didirikan oleh desa. Semua rencana usaha ini akan dikaji dan dikelola oleh BUMDes.

Sementara ini Desa dan BUMDes Panyanggar belum bergerak dalam bidang usaha yang berkaitan dengan pertanian meskipun sebagian besar warganya mendapatkan penghasilan sebagai petani dan citra Desa Cipta Karya sebagai lumbung padi karena sudah banyak masyarakat yang berkecimpung di dalam usaha ini. BUMDes Panyanggar Desa Cipta Karya tidak ingin memiliki usaha bidang pertanian yang sama dengan koperasi, pertimbangan lainnya adalah karena adanya bantuan pemerintah ataupun usaha yang sudah dijalankan masyarakat selama ini. BUMDes tidak ingin mengganggu usaha masyarakat yang sudah ada karena BUMDes bukan semata-mata mencari keuntungan namun seimbang juga bagi kepentingan masyarakat dan dapat turut membuat terjadinya perubahan sosial di masyarakat melalui kegiatan usaha yang tidak luput dari berbagai tantangan yang harus dihadapi. BUMDes merupakan pilar kegiatan ekonomi di desa yang berfungsi sebagai lembaga sosial (sosial institution) dan komersial (commercial institutions). Dalam menjalankan usahanya prinsip efisiensi dan efektifitas harus selalu ditekankan. Dengan demikian diharapkan keberadaan BUMDes mampu mendorong dinamisasi kehidupan ekonomi di pedesaan. (Purnama\& Ummur, 2019).

Desa dan BUMDes juga sudah menjajaki usaha dalam bidang energy yaitu usaha pertamini atau pertades, 
pertamina desa dengan bekerjasama dengan pertamina, dan harapannya di tahun 2025 sudah bisa tercapai. Hal ini masih dalam pengkajian untuk melihat kondisi lahan dan pertimbangan lainnya seperti dampak dari usaha pertades bagi kios-kios masyarakat. Kreativitas BUMDes untuk mencari usaha atau pun menjalankan usaha tidak terlepas dari perannya sebagai wira usaha sosial sehingga pada saat menentukan unit usaha yang dijalankan perlu mempertimbangkan secara matang dampak bagi masyarakat yang sebelumnya telah menjalankan usaha tersebut. BUMDes yang berperan sebagai wira usaha sosial selalu melibatkan diri dalam proses inovasi, adaptasi, pembelajaran yang terus menerus, bertindak tanpa menghiraukan berbagai hambatan atau keterbatasan yang dihadapinya dan memiliki akuntabilitas dalam mempertanggungjawabkan hasil yang dicapainya kepada masyarakat. (Sofia, 2015)

\section{PENUTUP}

\section{SIMPULAN}

Pemberian modal usaha atau dana penyertaan modal yang digelontorkan desa kepada BUMDes adalah berupa hibah modal untuk menjalankan usaha yang berasal dari pemanfaatan potensi dan aset desa yang diharapkan dapat member keuntungan berkelanjutan bagi pendapatan asli desa, dan berdampak pada perekonomian masyarakat serta memberikan lapangan pekerjaan bagi masyarakat sehingga masyarakat desa menjadi sejahtera. Pemberian kepercayaan bagi BUMDes untuk mengelola unit usaha desa perlu pendampingan dan pengawasan yang baik dan teratur oleh badan pengawas dan Pembina BUMDes, dalam hal ini adalah Kepala Desa dan Badan Permusyawaratan Desa. Sinergi yang telah terbentuk antara Kepala Desa, BPD dan Pengurus Bumdes karena adanya kerjasama dengan komunikasi yang terjalin dengan baik serta kreativitas dalam mewujudkan visi-misi Kepala Desa untuk berinovasi meningkatkan kesejahteraan desa dengan membangun unit-unit usaha yang seimbang dengan kepentingan masyarakat akan dapat mendukung keberlanjutan program pembangunan desa untuk meningkatkan kesejahteraan masyarakat.

\section{SARAN}

Motivasi dan semangat membangun desa dengan menjalankan unit-unit usaha dengan dana dari dana penyertaan modal dana desa hendaknya terus dijaga terutama saat unit-unit usaha semakin berkembang dan fokus usaha semakin melebar. Perluasan usaha perlu ditopang oleh kemampuan Sumber Daya Manusia yang mumpuni di bidangnya dan berintegritas serta dilakukan secara professional sehingga keberlanjutan pembangunan desa dapat terus berjalan meskipun kelak terjadi pergantian kepemimpinan. Pelatihan-pelatihan pengembangan kualitas insane perlu terus dilakukan serta peninjauan secara berkala keterlibatan masyarakat dalam pengelolaan dan pemanfaatan BUMDes bagi kesejahteraan masyarakat. 


\section{DAFTAR PUSTAKA}

Alhadar, S. 2016. Pengembangan Objek Wisata Pemandian Air Terjun Bondula Oleh Dinas Kebudayaan Dan Pariwisata Kabupaten Gorontalo Utara. Publik: Jurnal Manajemen Sumber Daya Manusia, Administrasi Dan Pelayanan Publik, III(1), 29-38.

Andreas, R. 2020. Pjs. Bupati Bengkayang Lantik 50 Kepala Desa Se-Kabupaten Bengkayang Periode 2020-2026. Beritatrends.Com. https://beritatrends.com/2020/02/19/ pjs-bupati-bengkayang-lantik-50kepala-desa-se-kabupatenbengkayang-periode-2020-2026/

Chintary, V., \& Lestari, A. 2016. Peran Pemerintah Desa Dalam Mengelola Badan Usaha Milik Desa. Jurnal Ilmu Sosial Dan Ilmu Politik Universitas Tribhuwana Tunggadewi, 5(2), 101802.

Dedi. 2020. Ribuan pengunjung datangi obyek wisata Bukit Sepancong Bengkayang.

Kalbar.Antaranews.Com. https://kalbar.antaranews.com/berita/ 433678/ribuan-pengunjung-datangiobyek-wisata-bukit-sepancongbengkayang

Fifianti, F., Alyas, A., \& Mone, A. 2018. Peran Pemerintah Desa Dalam Pengembangan Badan Usaha Milik Desa Di Desa Patani Kecamatan Mappkasunggu Kabupaten Takalar. Kolaborasi : Jurnal Administrasi Publik, 282. https://doi.org/10.26618/kjap.v4i3.1
644

Kiwi. 2020. Pemda Bengkayang Luncurkan Tiga Paket Wisata Keberlanjutan di Desa Cipta Karya. Www.Suarapemredkalbar.Com. https://www.suarapemredkalbar.com /read/bengkayang/02112020/pemdabengkayang-luncurkan-tiga-paketwisata-keberlanjutan-di-desa-ciptakarya\#

Kurniasih, D., \& Wijaya, S. S. 2017. Kegagalan Bisnis Pemerintah Desa ( Studi tentang Relasi BisnisPemerintah pada Pengelolaan Badan Usaha Milik Desa di Kabupaten Banyumas ). JPSI (Journal of Public Sector Innovations), 1(2), 66-72.

Maruhun, \& Thatok Asmony. 2019. Menyibak Tabir Pengelolaan Dana Desa Dari Perspektif Habermas. Akurasi: Jurnal Studi Akuntansi Dan Keuangan, 1(1), 63-75. https://doi.org/10.29303/akurasi.v1i1 .5

Miles, M. B., Huberman, A. M., \& Saldana, J. 2014. Qualitative Data Analysis 3rd Edition. SAGE Publication,Inc.

Pio, R. J. 2011. Pemberdayaan Kapasitas Kewirausahaan Kelompok Usaha Kecil. Journal of Business Studies, 2(3), 99-100.

Purnama, S., \& Ummur, S. W. 2019. Analisis Kinerja Badan Usaha Milik Desa (Bumdes) Didesa Pohuwato Kabupaten Pohuwato. Accountia Journal, 03(2), 425-442.

Saputra, R. 2017. Peranan Badan Usaha Milik Desa (Bumdes) Sebagai 
Implementasi Ekonomi Kreatif

Dalam Rangka Pemberdayaan

Masyarakat Desa Jalancagak

Kecamatan Jalancagak Kabupaten

Subang Provinsi Jawa Barat.

TRANSFORMASI: JURNAL MANAJEMEN PEMERINTAHAN, 9(1), 15-31.

Sofia, I. P. 2015. Konstruksi Model

Kewirausahaan Sosial (Social

Entrepreneurship) Sebagai Gagasan

Inovasi Sosial Bagi Pembangunan

Perekonomian. Jurnal Universitas

Pembangunan Jaya, 2(2), 2-23.

Sudarko, \& Tjitropranoto, P. 2018.

Telaah Perubahan Paradigma

Kewirausahaan dari Perspektif

Inovasi Ekonomi dan Sosial. Jurnal

Ilmiah Respati, 9(2), 1-1.

http://ejournal.urindo.ac.id/index.ph

$\mathrm{p} /$ pertanian/article/view/298

Sulasmi, S. 2017. Peran Variabel

Perilaku Belajar Inovatif, Intensitas

Kerjasama Kelompok, Kebersamaan

Visi Dan Rasa Saling Percaya

Dalam Membentuk Kualitas Sinergi.

EKUITAS (Jurnal Ekonomi Dan

Keuangan), $13(2), \quad 222$.

https://doi.org/10.24034/j25485024.

y2009.v13.i2.2138 